"Assessment of foreign direct investment, export and economic growth on the example of Kazakhstan"

$\begin{array}{ll}\text { Tolkyn Azatbek } \\ \text { AUTHORS } & \text { Altay Ramazanov }\end{array}$

Altay Ramazanov

Tolkyn Azatbek and Altay Ramazanov (2016). Assessment of foreign direct ARTICLE INFO investment, export and economic growth on the example of Kazakhstan. Investment Management and Financial Innovations, 13(4), 130-135. doi:10.21511/imfi.13(4).2016.11

DOI http://dx.doi.org/10.21511/imfi.13(4).2016.11

RELEASED ON Thursday, 15 December 2016

JOURNAL "Investment Management and Financial Innovations"

FOUNDER LLC "Consulting Publishing Company "Business Perspectives"

NUMBER OF REFERENCES

0
NUMBER OF FIGURES

0

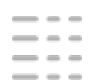

NUMBER OF TABLES

0

(C) The author(s) 2022. This publication is an open access article. 
Tolkyn Azatbek (Kazakhstan), Altay Ramazanov (Kazakhstan)

\title{
Assessment of foreign direct investment, export and economic growth on the example of Kazakhstan
}

\begin{abstract}
The article considers the problem of estimating the communication of foreign direct investment, net exports and economic growth. The Republic of Kazakhstan is taken. As an example, based on the method of calculation of the gross domestic product (GDP) expenditure and using the method of regression analysis, the impact of foreign direct investment (FDI) and net exports to GDP and interaction of FDI and net exports as components of GDP are evaluated.
\end{abstract}

Keywords: investment, FDI, GDP, net exports, economic growth, correlation and regression analysis.

JEL Classification: A10, C20, E22, F37.

\section{Brief literature review}

An important role in the formation of the methodological framework for assessing the effectiveness of investment activity played a theoretical the exploration classics theories of FDI: C. Kindleberger (2010), B. Blonigen (2007), J. Dunning (1998), J. Markusen, (2000) studied the issues related to the causes and consequences of the movement of capital. Special contribution in identifying the impact of FDI on economic development of the recipient country has made, whether academic economists who developed the concept of FDI: K. Akamatsu, R. Vernon, V.A. Launhardt, Palander T., G. von Thünen, C. Heimer, X. Chenery, P. Eckstein. There are the results of studies of contemporary authors. For example, Sajid Anwar, Lan Phi Nguyen (2011) in 2011 conducted a study that shows the impact of FDI on net exports slightly over the period, but significant positive correlation seen after the Asian financial crisis (1998-2000).

The result of the study conducted by Xiaolan Fu, V.N. Balasubramanyam (2005) shows that FDI has a significant positive effect on export growth. Exports, in turn, by means of injections of FDI is essentially «vent for surplus» for labor that contributes to the growth of employment. Ramazanov, A., B.Uteev (2013) conducted a study of foreign portfolio investment in the emerging stock market. The result of the study - portfolio foreign investment affect the development of the stock market, which has an impact on economic growth.

The research made by authors in Kazakhstan shows only analysis of value of FDI attraction and its allocation by economic sectors. For example, the articles of A.,Waikar, L., Jepbarova, S., Lee(2011),

(C) Tolkyn Azatbek, Altay Ramazanov, 2016.

Tolkyn Azatbek, the Doctor of Economy science Professor, L. N. Gumilyov Eurasian National University, Astana, Republic of Kazakhstan.

Altay Ramazanov, the Doctor of Economy science, expert of Education and Science Ministry of the Republic of Kazakhstan;laureate of USAID.
A.Khoich (201). Other publications are considering factors of economic growth in Post-Soviet countries. For example, L., Melnyk (2011) in his study, underlines significance of additional factor of economic growth as country's policy.

The purpose of the study is to determine the components have a significant impact on the change of economic growth and evaluation of their influence.

\section{Results of the study}

Kazakhstan is a leader in attracting investments on the post-soviet space. According to the UN Trade and Development Conference (UNCTAD) in 2014 Kazakhstan took the 19th place among the top 20 leading countries in terms of attracting foreign direct investments. In 2014 the gross inflow of FDI to Kazakhstan reached 28.9 billion dollars. Kazakhstan takes the second place among the CIS countries in terms of the volume of accumulated FDI per capita, which is 12 067.6 US dollars.

Gross inflow of FDI to Kazakhstan from 2007 to 2015 amounted to $\$ 183.71$ billion US dollars Fig. .1)

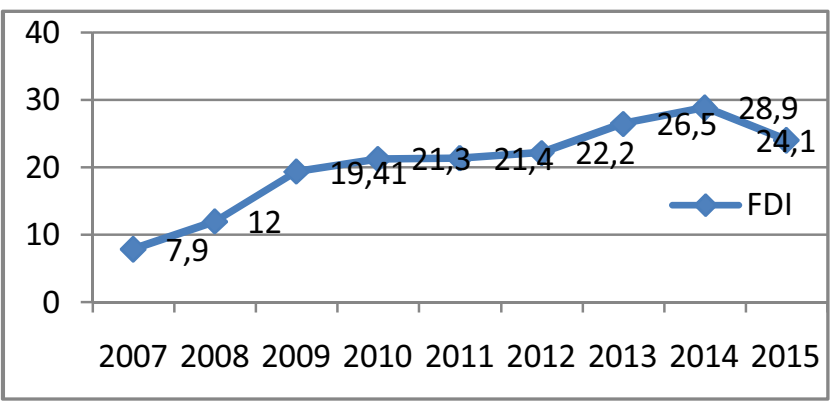

Fig. 1. The dynamics of FDI in Kazakhstan from 2007 to 2015, billion US dollars

Note: compiled by the author based on statistics of the National Bank of Kazakhstan.

Efficiency of investments is important for the host country's economy: an increase in the scale of the investment without a certain level of its efficiency does not lead to sustained economic growth. Therefore, in this study, we aim to identify and evaluate the mutual investments in the nature of 
economic growth and determine the prospects for the implementation of FDI policy in Kazakhstan.

According to the method of calculating, the GDP expenditure consists of the following parameters (1)

The final GDP $=$ consumption + investment + Government spending + Net exports (exports imports)
From this equality to detect interference and to determine its extent, it is necessary to provide at least two indicators. As such we have chosen indicators of FDI and net exports. The time period taken last 6 years. FDI - $\mathrm{x}_{1}$ (bln. Dollars. US / year), net exports at current prices, the total value for the year - $\mathrm{x}_{2}$ (bln Dollars. US/year), and as a result of the country's GDP (y) (Table 1).

Table 1. Key figures based on correlation analysis

\begin{tabular}{|l|c|c|c|c|c|c|}
\hline \multicolumn{1}{|c|}{ Indicator } & 2010 & 2011 & 2012 & 2013 & 2014 & 2015 \\
\hline GDP & 133.5 & 115.3 & 148,0 & 188.0 & 203.5 & 220.4 \\
\hline FDI & 21.3 & 21.4 & 22.2 & 26.5 & 28.9 & 24.2 \\
\hline Export & 71.0 & 43.0 & 60.0 & 84.3 & 86.5 & 82.5 \\
\hline Import & 37.9 & 28.4 & 31.0 & 36.9 & 46.4 & 48.8 \\
\hline Pure export & 33.1 & 14.6 & 29.0 & 47.4 & 40.1 & 33.7 \\
\hline
\end{tabular}

Note: compiled by the authors according to the site of the National Bank of Kazakhstan.

Method of evaluating interference selected indicators to determine the correlation - regression analysis. This method of assessment was incubated APRO sponsored by the example of evaluating the performance of the innovation infrastructure in the Republic of Kazakhstan (Azatbek, 2012).

To assess the strength of association in the theory of correlation scale is applied English Statistics R. Cheddok (1925), which is to determine the binding forces (weak and strong (tight)) built scale:

$0.1<$ rxy $<0.3$ : weak;

$0.3<$ rxy $<0.5$ : moderate;

$0.5<$ rxy $<0.7$ : noticeable;

$0.7<$ rxy $<0.9$ : high;
$0.9<$ rxy $<1$ : very high.

Calculate the correlation coefficient for the linear relationship and existing factors $-\mathrm{x}_{1}$ and $\mathrm{x}_{2}$. To find the coefficient of correlations is necessary to find the following parameters: dispersion srednekvadcratic deviation of the investment and the standard deviation of GDP.

The parameters of the regression equation.

Sample means $(2,3,4)$.

$\overline{\mathrm{x}}=\frac{\sum \mathrm{xi}}{\mathrm{n}}=24.08$

regression analysis of FDI (Table 2).

Table 2. Initial data for the regression analysis of FDI

\begin{tabular}{|l|c|c|c|c|c|c|c|c|}
\hline & FDI & GDP & & & & $\begin{array}{c}\text { The absolute } \\
\text { error of } \\
\text { approximation }\end{array}$ & $\begin{array}{c}\text { The absolute } \\
\text { error of } \\
\text { approximation }\end{array}$ & $\begin{array}{c}\text { The relative } \\
\text { error of } \\
\text { approximation }\end{array}$ \\
\hline & $\mathrm{x} 1$ & $\mathrm{y}$ & $\mathrm{yx} 1$ & $\mathrm{x}^{2}$ & $\mathrm{y}^{2}$ & $\mathrm{y}^{\wedge}$ & $\mathrm{y}-\mathrm{y}^{\wedge}$ & $\mathrm{Ai}^{\mathrm{n}}$ \\
\hline 2010 & 21.3 & 133.5 & 2843.6 & 453.7 & 17822.3 & 138.9 & -5.4 & 0.0 \\
\hline 2011 & 21.4 & 115.5 & 2471.7 & 458.0 & 13340.3 & 139.9 & -24.4 & 0.2 \\
\hline 2012 & 22.2 & 148 & 3285.6 & 492.8 & 21904.0 & 148.3 & -0.3 & 0.0 \\
\hline 2013 & 26.5 & 188 & 4982.0 & 702.3 & 35344.0 & 193.6 & -5.6 & 0.0 \\
\hline 2014 & 28.9 & 203.5 & 5881.2 & 835.2 & 41412.3 & 218.8 & -15.3 & 0.1 \\
\hline 2015 & 24.2 & 220.4 & 5333.7 & 585.6 & 48576.2 & 169.4 & 51.0 & 0.2 \\
\hline Total & 144.5 & 1008.9 & 24797.7 & 3527.6 & 178398.9 & 1008.9 & 0.0 & 0.6 \\
\hline approximately & 24.1 & 168.2 & 4132.9 & 587.9 & 29733.2 & 168.2 & 0.0 & 0.1 \\
\hline
\end{tabular}

Note: compiled by the authors based on their own calculations.

For factor $\mathrm{x}_{1}$. ie investments after the substitution data into the formula, the following correlation coefficient $\mathrm{r}_{1}(7)$ :

$\operatorname{rxy}=\frac{\overline{x \cdot y}-\bar{x} \cdot \bar{y}}{S(x) \cdot S(y)}=0.78$,
Where $\sigma \mathrm{x}_{1}$ and $\sigma \mathrm{y}$ - standard deviation or the square root of the variance factor and resultant variable respectively.

The regression equation (estimated regression equation) has the form $(8,9)$. 
$\mathrm{b}=\mathrm{Sxy} /\left((\sigma \llbracket) \mathrm{x} \rrbracket^{\wedge} 2\right)=10,5$,

(8) In order to make better assessment of interdependence between indicators the coefficient of elasticity is calculated. The average coefficient of elasticity (E) shows how many percent the GDP changes from its average value when changing the investment of $1 \%$ of its average value.

$\mathrm{E}=1.51$.

The coefficient of determination (13)

$\mathrm{R}^{2}=0.78^{2}=0.6$,

but only if $x=0$ is close to the sampling values, final values of the calculations are presented in Table 3 .

Table 3. Final estimates in terms of $\mathrm{x}_{1}$.

\begin{tabular}{|l|l|l|c|c|c|c|}
\hline & $\begin{array}{c}\text { The } \\
\text { average } \\
\text { error of } \\
\text { approxi- } \\
\text { mation }\end{array}$ & $\begin{array}{c}\text { Simple } \\
\text { Linear } \\
\text { Regression } \\
\text { coefficient }\end{array}$ & $\begin{array}{c}\text { Simple } \\
\text { Linear } \\
\text { Regressi- } \\
\text { on } \\
\text { coefficien } \\
\mathrm{t}\end{array}$ & $\begin{array}{c}\text { The } \\
\text { standard } \\
\text { deviation } \\
(\mathrm{x})\end{array}$ & $\begin{array}{c}\text { The } \\
\text { standard } \\
\text { deviation } \\
(\mathrm{x})\end{array}$ & $\begin{array}{c}\text { Correl } \\
\text { ation } \\
\text { coe- } \\
\text { fficient }\end{array}$ \\
\hline & $\mathrm{A}$ & $\mathrm{b}$ & $\mathrm{a}$ & $\sigma \mathrm{x}$ & $\sigma \mathrm{y}$ & $\mathrm{r}_{1}$ \\
\hline $\begin{array}{l}\mathrm{X} \\
(\mathrm{F} \\
\mathrm{DI})\end{array}$ & 9.8 & 10.5157 & -85.1 & 2.8 & 38.2 & 0.78 \\
\hline
\end{tabular}

Note - compiled by the authors based on their own calculations

The average error of approximation (A) shows how many percent the actual values deviate from the calculated (11).

$\mathrm{A}=1 / \mathrm{n} \sum A i=1 / \mathrm{n} \times \sum_{t=1}^{n}\left|\frac{y-\mathrm{y}}{y}\right| \times 100 \%=9.8 \%$ ie in $60.07 \%$ of cases the changes in foreign direct investment result in changes in GDP. In other words, - the accuracy of the selection equation regression - the average. The remaining $39.93 \%$ of GDP changes are explained by factors not accounted for in the model (as well as specification error).

The impact of FDI on GDP can be characterized as follows: the relationship between foreign direct investment and gross domestic product is straightforward, because the correlation coefficient is positive and strong, as it is between 0.7 and 0.8 . The coefficient of determination shows that $60.07 \%$ of the changes in foreign direct investment result in changes in GDP. The regression coefficient $b=$ 10.52, meaning that an increase in foreign direct investment KZT1 GDP increased by 10.5 tenge (Figure 2).

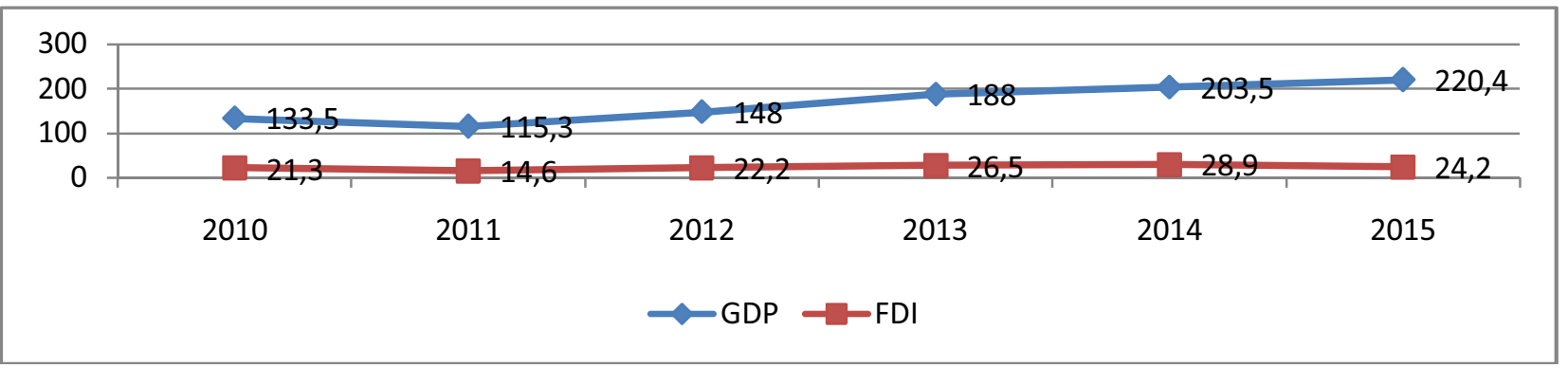

Fig. 2. Dynamics of GDP and FDI, mln. USD

Note - compiled by the authors based on the statistics website of the National Bank of the Republic of Kazakhstan.

Consider the effect of net exports to GDP. To this raw data for these calculations are presented in Table 4.

Table 4. Initial data for the regression analysis of export

\begin{tabular}{|l|c|c|c|c|c|c|c|c|}
\hline & Export & GDP & & & & $\begin{array}{c}\text { The absolute } \\
\text { error of } \\
\text { approximation }\end{array}$ & $\begin{array}{c}\text { The absolute } \\
\text { error of } \\
\text { approximation }\end{array}$ & $\begin{array}{c}\text { The relative } \\
\text { error of } \\
\text { approximation }\end{array}$ \\
\hline & $\mathrm{x} 2$ & $\mathrm{y}$ & $\mathrm{yx} 2$ & $\mathrm{x}_{2}{ }^{2}$ & $\mathrm{y}^{2}$ & $\mathrm{y}$ & $\mathrm{y}^{\wedge}$ & $\mathrm{y}^{\wedge}$ \\
\hline 2010 & 33.1 & 133.5 & 4418.9 & 1095.6 & 17822.3 & 168.6 & -35.1 & 0.3 \\
\hline 2011 & 14.2 & 115.5 & 1635.5 & 200.5 & 13340.3 & 119.2 & -3.7 & 0.0 \\
\hline 2012 & 29.0 & 148.0 & 4292.0 & 841.0 & 21904.0 & 157.9 & -9.9 & 0.1 \\
\hline 2013 & 47.4 & 188.0 & 8911.2 & 2246.8 & 35344.0 & 206.0 & -18.0 & 0.1 \\
\hline 2014 & 40.1 & 203.5 & 8160.4 & 1608.0 & 41412.3 & 186.9 & 16.6 & 0.1 \\
\hline 2015 & 33.7 & 220.4 & 7427.5 & 1135.7 & 48576.2 & 170.2 & 50.2 & 0.2 \\
\hline Total & 197.5 & 1008.9 & 34845.4 & 7127.6 & 178398.9 & 1008.9 & 0.0 & 0.8 \\
\hline approximately & 32.9 & 168.2 & 5807.6 & 1187.9 & 29733.2 & 168.2 & 0.0 & 0.1 \\
\hline
\end{tabular}

Note: compiled by the authors based on their own calculations. 
Calculate the ratio of the covariance.

$\operatorname{cov}(\mathrm{x}, \mathrm{y})=\overline{\mathrm{x} \cdot \mathrm{y}}-\overline{\mathrm{x}} \cdot \overline{\mathrm{y}}=269.88$

Calculate the close connection between the measure of selective linear correlation coefficient-to (15):

$\mathrm{rxy}=\frac{\overline{\mathrm{x} \cdot \mathrm{y}}-\overline{\mathrm{x}} \cdot \overline{\mathrm{y}}}{\mathrm{S}(\mathrm{x}) \cdot \mathrm{S}(\mathrm{y})}=0.7$

We define the standard deviation $(16,17)$

$$
\begin{aligned}
& \sigma \times 2=\sqrt[1]{\mathrm{x}^{2} \text { cp. }-x \mathrm{cp.}^{2}}=10.1, \\
& \sigma y=\sqrt[1]{\mathrm{y}^{2} \text { cp. }-y \mathrm{cp.}^{2}}=38.2,
\end{aligned}
$$

where $\mathrm{x}_{2}$ - the value of net exports; and - the value of GDP,

$\mathrm{x}$ ap. - The mean value of the trait.

Table 5. Final estimates in terms of $\mathrm{x}_{2}$

\begin{tabular}{|l|l|c|c|c|l|l|}
\hline & $\begin{array}{c}\text { The } \\
\text { average } \\
\text { error of } \\
\text { approximati } \\
\text { on }\end{array}$ & $\begin{array}{c}\text { Simple } \\
\text { Linear } \\
\text { Regressi } \\
\text { on } \\
\text { coefficie } \\
\mathrm{nt}\end{array}$ & $\begin{array}{c}\text { Simple } \\
\text { Linear } \\
\text { Regressi } \\
\text { on } \\
\text { coefficien } \\
\mathrm{t}\end{array}$ & $\begin{array}{c}\text { The } \\
\text { standard } \\
\text { deviation } \\
(\mathrm{x})\end{array}$ & $\begin{array}{c}\text { The } \\
\text { standard } \\
\text { deviation } \\
(\mathrm{x})\end{array}$ & $\begin{array}{c}\text { Correlat } \\
\text { ion } \\
\text { coeffici } \\
\text { ent }\end{array}$ \\
\hline 1 & $\mathrm{~A}$ & $\mathrm{~b}$ & $\mathrm{a}$ & $\sigma \mathrm{x}$ & $\sigma \mathrm{y}$ & $\mathrm{r}_{2}$ \\
\hline $\mathrm{X}_{2}$ & 12.8 & 2.6423 & 81.0 & 10.1 & 38.2 & 0.70 \\
\hline
\end{tabular}

Note - compiled by the authors based on their own calculations

To factor $\mathrm{x}_{2}$, is net exports after setting data, we obtain the following correlation coefficient $r_{2}$ :

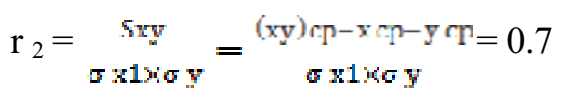

The average error of approximation (19)

$A=1 / 6 \sum A i \times 4,6=12.8 \%$

Simple Linear Regression coefficient (20)

$\mathrm{b}=\frac{\mathrm{Sxy}}{(\sigma) \mathrm{x}^{2}}=2.6$.

The coefficient of elasticity

$\mathrm{E}=0.52$.

The coefficient of determination

$\mathrm{R}^{2}=0.7^{2}=0.4889$.

From these data it is possible to observe the impact of net exports to GDP, which is a direct bond, as the coefficient of correlation, of positive, ranged from 0.5 to 0.7. Communication noticeable.

Simple Linear Regression coefficient: $b=2,6$. This means that an increase in net exports to GDP KZT1 increased by $2.6 \mathrm{~m}$.

The coefficient of determination of 0.48 , respectively, in $48.89 \%$ of cases the change in net exports lead to changes in GDP. The remaining $51.11 \%$ of GDP changes are explained by factors not accounted for in the model. Figure 3 shows the interaction of net exports and GDP.

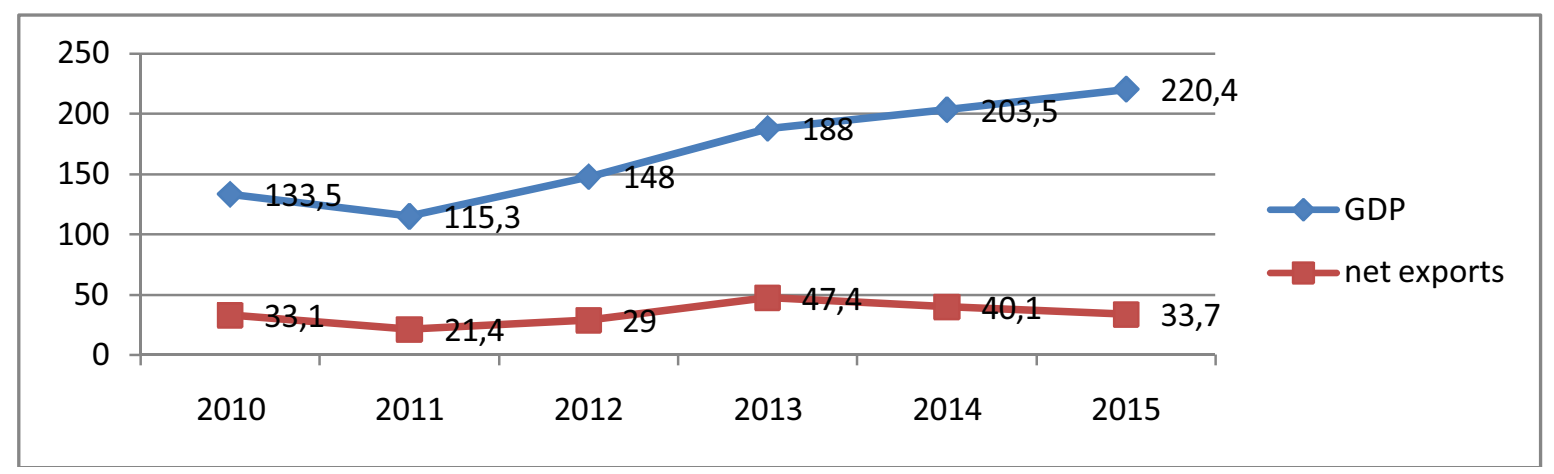

Fig. 3. Dynamics of GDP and net exports

Note: compiled by the authors based on the statistics website of the National Bank of the Republic of Kazakhstan.

For existing factors $\mathrm{x}_{1}$ and $\mathrm{x}_{2}$, ie FDI and net exports amounted Wim-multiple regression equation. Multiple regression equation is studying statistical relationships between productive and sign a number of factors affecting the result. On the basis of the available data will be analyzed in a multiple regression the following factors:

foreign direct investment $-\mathrm{x}_{1}$ (billion US dollars / year)

net exports $\mathrm{x}_{2}$ (US $\$$ bn / year).

These factors will check for multicollinearity, for which we calculate the correlation coefficient $\operatorname{rx}_{1} \mathrm{x}_{2}$, i.e., between factors $\mathrm{x}_{1 \mathrm{i}} \mathrm{x}_{2}$. Substituting the data available in the formula have the following meanings:

The calculated values closeness of the connection:

$$
\begin{aligned}
& \operatorname{rxy}=\frac{\overline{x \cdot y}-\bar{x} \cdot \bar{y}}{S(x) \cdot S(y)}=0.88 \\
& y x=\operatorname{rxy} \frac{x-\bar{x}}{S(x)} S(y)+\bar{y}=1.48 x-2.3
\end{aligned}
$$


e linear regression equation of the form (25)

$\mathrm{y}=1.48 \mathrm{x}-2.3$.

The regression coefficient $\mathrm{b}=1.48$. With the increase in FDI in Kazakhstan's economy by 1 unit, net exports increased by an average of 1.48 .

The regression coefficient $b$ undesirable to use for the direct evaluation of the impact of factors on a productive feature if there is a difference of units in a productive indicator and factor variable $\mathrm{x}$, in such cases the coefficient of elasticity is calculated. The average coefficient of elasticity $\mathrm{E}$ shows how the result $y$ will change in average percent from its average value when the factor $x$ changes on $1 \%$ from its average value.

In this case, the coefficient of elasticity (26) is greater than 1 . Thus, if FDI changes on $1 \%$ net exports will change by more than $1 \%$, which shows the significant impact of FDI on net exports.
$\mathrm{E}=1.08$

The coefficient of determination

$\mathrm{R}^{2}=0.88^{2}=0.7729$

ie in $77.29 \%$ of FDI changes lead to a change in net exports. In other words - picking accuracy of the regression equation - high.

The average error of approximation

$\mathrm{A}=1 / 6 \sum A i \times 0.8=\%$

Simple Linear Regression coefficient (29)

$b=\frac{S x y}{(\sigma) x^{2}}=2,6$

According to the analysis of the relationship between two factors of FDI and net exports, we can say that the relationship between them is strong and direct correlation coefficient 0.88 . Figure 4 shows the dynamics of indicators of FDI and net exports.

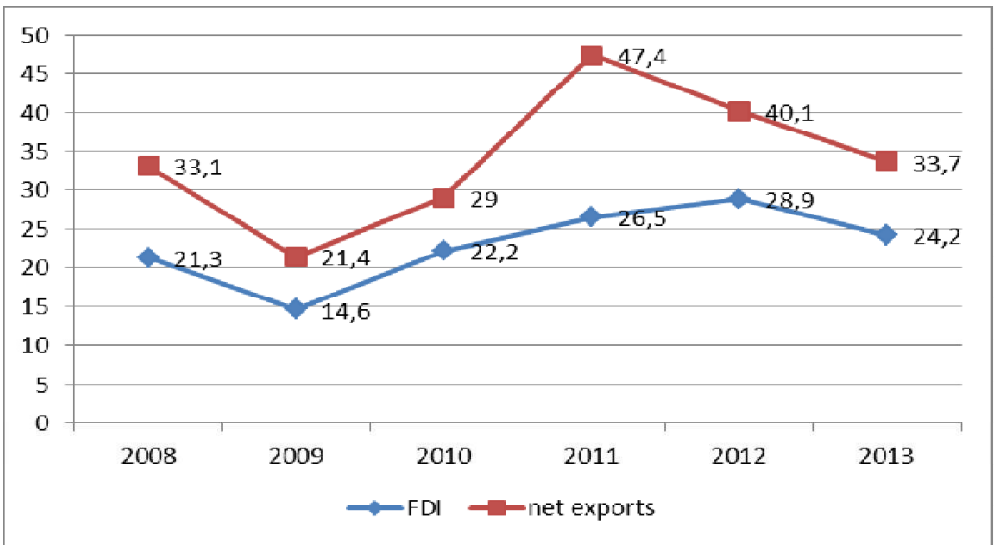

Fig. 4. Dynamics of FDI and net exports

Note - compiled by the authors based on the statistics website of the National Bank of the Republic of Kazakhstan.

The regression coefficient of 2.6. This means that an increase in FDI KZT1 net exports increase by 2.6 tenge. In other words - FDI significantly affect net exports. This effect can be explained by the fact that the largest share in the export of mineral products, including oil, gas condensate, ferrous and non-ferrous metals (Figure 5).

The main inflow of FDI was directed in these areas of activity during the study period. In other words, FDI in these areas are the main factor in the growth of production.

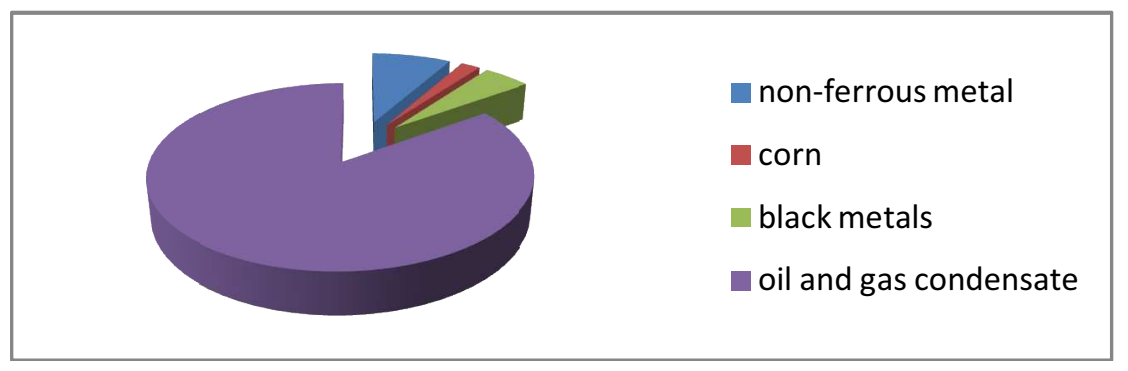

Fig. 5. Commodity structure of export of Kazakhstan billion US dollars, 2015

Note: compiled by the authors according to the Agency of the Republic of Kazakhstan on Statistics.

\section{Output}

As a result of this work structural, sectoral, correlation and regression analysis was carried out, which revealed the existence of a multiplier effect, 
i.e., positive impact of foreign direct investment on economic growth and exports to Kazakhstan.

It should be noted that the multiplier effect works in the opposite direction. With a slight reduction in investment spending can occur a significant reduction in income. Therefore, for stable and balanced functioning of the economy should provide a certain value of the coefficient of animation to create conditions for the smooth implementation of the investment process should be provided.

Multiplier effect, investments have a positive impact on gross domestic product. FDI and exports have a positive impact on economic growth.

The results of the analysis revealed a significant relationship between the indicator of FDI, net exports and GDP in Kazakhstan. A model demonstrates a strong dependence of the economy of Kazakhstan on external investments.

Correlation and regression analysis made it possible to reveal the existence of a multiplier effect, in other words, the positive impact of FDI on economic growth and export in Kazakhstan. For example, 1 tenge invested foreign direct investment increases the GDP of Kazakhstan by 10.5 tenge.
FDI is a source of structural reforms in the real sector of Kazakhstan. They are the direct source of investment in the production of goods and services, allowing to update the production, to ensure the involvement of the latest technology, global technology, know-how and advanced management methods. As a result, there is an increase in labor efficiency and growth in production and exports.

It should be noted that the multiplier effect works in the opposite direction. A slight reduction in investment expenditures can occur a significant reduction in income. Therefore, it is necessary to provide a specific value multiplication factor for a stable and balanced functioning of the economy, to create conditions for the smooth implementation of the investment process.

The study has practical implications, since it gives the opportunity to evaluate, to predict the expected effect from attraction of FDI in the future. Kazakhstan should consider attracting investment as a priority in national policies and provide a redistribution of investment funds in the processing industry and production of high value added finished products. It will help to achieve a positive long term multiplier effect.

\section{References}

1. C. Kindlberger, R. Aliber. (2010). The global financial crisis. Manias, panics, crashes. Peter: LLC Leader [Rossiya], 532. Available at: http://www.nowandfutures.com/large/Manias, Panics,andCrashes.pdf.

2. B.A. Blonigen et al. (2007). FDI in Space: Spatial Autoregressive Relationships in Foreign Direct Investment, European Economic Review, V. 51 (5), pp. 1303-1325. Available at: http://papers.ssrn.com/sol3/papers.cfm?abstract_id=616786.

3. Dunning, J.H. (1998). Location and the Multinational Enterprise: a Neglected Factor? Journal of International Business Studies, V. 29 (1), pp. 45-66. Available at: http://papers.ssrn.com/sol3/papers.cfm?abstract_id=1808491.

4. Markusen, J.R. (2000). Foreign Direct Investment and Trade. Adelaide: University of Adelaide.

5. Paul Fisher. (2004). FDI in Russia: 5 Steps to Success. Publisher "Flint" [Rossiya]. Available at: http://www.palgraveconnect.com/pc/doifinder/view/10.1057/9780333977590.

6. Anwar, S., Lan Phi Nguyen. (2011). FDI and Trade: the Case of Vietnam, Research in International Business and Finance, Vol. 25, Issue.

7. Xiaolan, Fu, Balasubramanyam, V.N. (2005). Exports, Foreign Direct Investment and Employment: The Case of China, The World Economy, Vol. 28 (4), from http://papers.ssrn.com/sol3/papers.cfm?abstract_id=704705

8. Ramazanov, A., B. Uteev. (2013). Regulators of the stock market of Kazakhstan, Actual problems of the economy, 4, pp. 463-471, Ukraina. Available at: http://www.irbis-nbuv.gov.ua/cgibin/irbis_nbuv/cgiirbis_64.exe?Z21ID=\&I21DBN=UJRN\&P21DBN=UJRN $\& \mathrm{~S} 21 \mathrm{STN}=1 \& \mathrm{~S} 21 \mathrm{REF}=$.

9. Avinash Waikar, Leyla Jepbarova, Sang H. Lee, Lara Gardner and Jay Johnson. (2011). The Impact of Foreign Direct Investment on Kazakhstan's Economy: A Boon or a Curse, International Journal of Business and Social Science, vol. 2 (22), December, pp. 92-98. Available at: https://www.researchgate.net/publication/260136865_Impact_of_Foreign_ Direct_Investment_on_Kazakhstan's_Economy_A_Boon_or_a_Curse.

10. Aizhan, Khoich, Madiyarova Diana. (2011). Impact of Foreign Direct Investment on Economic Growth in Kazakhstan, International Proceedings of Economics Development \& Research, Vol. 10, p. 414. Available at: http://connection.ebscohost.com/c/articles/74613232/impact-foreigndirect-investment-economic-growth-kazakhstan.

11. Leonid Melnyk, Oleksandr Kubatko, Serhiy Pysarenko. (2014). The impact of foreign direct investment on economic growth: case of post communism transition economies, Problems and Perspectives in Management, Vol. 12, Issue 1. Available at: http://businessperspectives.org/journals_free/ppm/2014/PPM_2014_1_Melnyk.pdf.

12. Online media “Zakon.kz". http://www.zakon.kz/4590245-kazakhstan-voshel-v-top-20-stran.html.

13. Prime Minister of the Republic of Kazakhstan (official website). https://primeminister.kz/news/show/21/v- 
kazahstane-po-itogam-2012-goda-vvp-na-dushu-naselenija-sostavil-bolee-12-tys-dollarov-ssha-glavaminekonomiki-/05-03-2013?lang=ru.

14. National Bank of Kazakhstan. Available at: www.nationalbank.kz/?docid $=680 \&$ switch $=$ russian.

15. Azatbek, T. (2012). Model evaluate the effectiveness of the innovation infrastructure of Kazakhstan, Actual problems of the economy, 12, pp. 340-346 [Ukraina]. Available at: irbis-nbuv.gov.ua/cgibin/irbis.../cgiirbis_64.exe?

16. Chaddock, R.E. (1925). Principles and Methods of Statistics by Robert Emmet Chaddock. Boston Houghton Mifflin Company. Available at: http://www.jstor.org/stable/1813712?seq= 1\#page_scan_tab_contents.

17. Ministry of National Economy of the Republic of Kazakhstan, Statistics Committee (official website). Available at: www.stat.gov.kz/faces/wcnav externalId/homeNumbersInvestment? afrLoop=88723816323559\#\%4 0\%3F_afrLoop\%3D88723816323559\%26_adf.ctrl-state\%3D19fxp8j4se_100. 